\title{
Disability as a Problem of Humanity in Scottish Enlightenment Thought
}

\author{
Esme Cleall ${ }^{1}$ (I) and Onni Gust ${ }^{2}$ (D) \\ ${ }^{1}$ Department of History, University of Sheffield, Sheffield, UK and ${ }^{2}$ Department of \\ History, University of Nottingham, Nottingham, UK \\ Email: e.r.cleall@sheffield.ac.uk; onni.gust@nottingham.ac.uk
}

\begin{abstract}
This article makes a case that disability, particularly visual, hearing, and speech impairments, played a significant role in Scottish Enlightenment thought. Focusing on the work of Dugald Stewart, and in particular on his essay 'Some account of a boy born blind and deaf, we argue that disability was a deep preoccupation of Scottish Enlightenment thinkers who used it as a test case for various important philosophical questions including those concerning 'human nature' and the limits of humanity. The article starts by situating the philosophical debate in the context of lived experiences of, and proximity to, impairment. The second part offers a close reading of Stewart's text 'Some account', about James Mitchell, a fourteen-year-old deafblind boy living in the Scottish Highlands. The third part examines how disability operated in relation to other hierarchies of difference that have been demonstrated to have been central to Enlightenment thought, in particular that of race. Overall, the contribution this article makes is to introduce disability as an important, if currently overlooked, category in Scottish Enlightenment thought that needs further investigation.
\end{abstract}

\section{I}

James Mitchell is the kind of person whom historians struggle to find in the archives and about whom they rarely write. Born in Ardclach in Nairnshire in the Scottish Highlands, Mitchell was deafblind, never received an education, did not marry or have children, and left no known records himself. With the notable later exceptions of the Americans Laura Bridgeman (1829-89) and Helen Keller (1880-1968), deafblind people, perhaps even more so than differently disabled populations, have long been almost completely absent from historical research. ${ }^{1}$ This historiographical oversight seems to reflect

\footnotetext{
${ }^{1}$ See, for example, Elisabeth Gitter, The imprisoned guest: Samuel Howe and Laura Bridgman, the original deaf-blind girl (New York, NY, 2001); David Wagner, The miracle worker and the transcendentalist: Annie Sullivan, Franklin Sanborn, and the education of Helen Keller (Abingdon, 2015).

(C) The Author(s) 2021. Published by Cambridge University Press. This is an Open Access article, distributed under the terms of the Creative Commons Attribution licence (http://creativecommons.org/licenses/by/4.0), which permits unrestricted re-use, distribution and reproduction, provided the original article is properly cited.
} 
the often-marginal position disabled people were assumed to have occupied in society, as well as their not infrequent marginalization physically in institutions. Although now burgeoning, the history of disability has in some ways reflected this marginalization remaining somewhat peripheral to 'mainstream' historical research. ${ }^{2}$ Significant historiographical areas, perhaps none more so than intellectual history, have continued to be written without reference to either the concept or experience of disability. ${ }^{3}$ What we intend to do in this article is to argue that, contrary to this historiographical neglect, disability particularly visual, hearing, and speech impairments - played an overlooked but fundamental role in Scottish Enlightenment thought. We do this first through exploring disability in its own right, and secondly by placing disability in relation to that other key idea of the Enlightenment: race.

It is worth noting here that by 'disability' we refer to social and cultural constructions of impairment, an unstable category that manifests differently and is inflected differently across time and space. ${ }^{4}$ Indeed, looking back to the Scottish Enlightenment, the idea of 'disability', at least in that specific formulation, is to some extent anachronistic because the various impairments that today constitute 'disability' were not grouped together in the same way. The conflation between different types of visible and invisible disability had not yet been cemented, nor had eugenicist ideas, which posited disability as something to be eliminated, been constituted in their modern form. Nonetheless, as this article seeks to demonstrate, something akin to what we now call 'disability' was deeply preoccupying in eighteenth-century Enlightenment thought, and informed fundamental moral, epistemological, and ontological questions over the nature of humanity and human societal development. We make the argument that disability was not only a condition experienced by many Enlightenment thinkers and those in their social networks, but proved conceptually stimulating to a whole range of debates central to their thinking, including those about the relationship between humans and animals, what role the senses played on the mind, and the role that experience played in human development and learning.

To make this argument in an article-length piece requires us to be selective, and our focus here is on the writing and lectures of Dugald

\footnotetext{
${ }^{2}$ For important works on the period, see, for example, David M. Turner, Disability in eighteenthcentury England: imagining physical impairment (New York, NY, and London, 2012); Helen Deutsch and Felicity Nussbaum, eds., 'Defects': engendering the modern body (Ann Arbor, MI, 2000); and Felicity Nussbaum, The limits of the human: fictions of anomaly, race, and gender in the long eighteenth century (Cambridge, 2003).

${ }^{3}$ For important exceptions, see Chris Mounsey's edited collection The idea of disability in the eighteenth century (Lanham, MD, and Plymouth, 2014), particularly Jess Keiser, 'What's the matter with madness? John Locke, the association of ideas, and the physiology of thought', and Emile Bojesen, 'Thomas Reid: power as first philosophy', pp. 49-70 and 91-104. See also Nicholas Mirzoeff, Silent poetry: deafness, sign and visual culture in modern France (Princeton, NJ, 1995); Jonathan Rée, I see a voice: a philosophical history of language, deafness and the senses (London, 1999).

${ }^{4}$ Mike Oliver, 'The social model of disability: thirty years on', Disability \& Society, 28 (2013), pp. 1024-6; Susan Wendell, The rejected body (New York, NY, 1996). See also Dan Goodley, Dis/ability studies: theorizing disablism and ableism (Abingdon, 2014).
} 
Stewart (1753-1828), Professor of Moral Philosophy at the University of Edinburgh between 1780 and 1810, and, in particular, his encounter with James Mitchell, an account of which was first published in 1815. Although we focus on the Scottish Enlightenment, Stewart, like all his colleagues, was embedded in wider European and colonial networks. For example, Stewart made good use of Diderot's 'Letter on the blind for the use of those who see' (1749), which in turn cited examples of blind people, philosophers, and physicians in Prussia, France, and England. ${ }^{5}$ Stewart also had close connections to elite American settler colonists, including Thomas Jefferson, British imperial administrators in India, and colonial adventurers to parts of Africa. ${ }^{6}$ We begin by providing a general context for disability in Enlightenment thought, before concentrating on Dugald Stewart's essay on James Mitchell as a particular case-study. We then readjust the focus to think about the wider implications of this interest in disability including the relationship between disability and other categories of 'difference' in Enlightenment thought, in particular, 'race'.

\section{II}

In eighteenth-century Britain, impairments such as blindness, deafness, mobility difficulties, chronic pain, and cognitive difficulties were highly prevalent in everyday life. Due to limited record-keeping and varying definitions, the absolute numbers of disabled people are very difficult to calculate with any accuracy. However, it is reasonable to assume that there were many disabled people due to high incidences of contagious diseases (such as smallpox and measles), which, when survived, often left disabling or disfiguring impairments, the consequences of agricultural and early industrial accidents, and limited medical and technological interventions for what today might be considered 'correctable' impairments. This high incidence of disability renders it unsurprising that this issue not only affected Enlightenment thinkers themselves, but had profound effects on their friends, family, and acquaintances.

The philosopher Thomas Reid (1710-96), Professor of Moral Philosophy at the University of Glasgow, had a hearing impairment, whilst his colleague, James Beattie (1735-1803), Professor of Moral Philosophy at Marischal College, Aberdeen, suffered from 'tender lungs', which prevented him from making progress with his philosophical work during the winter. ${ }^{7}$ Josiah Wedgwood, the Staffordshire potter and member of the Lunar Society, was lame in one leg as a result of smallpox in childhood, and later had to have his leg amputated. ${ }^{8}$ His son, Tom Wedgwood, who studied under Stewart and was resident in the Stewarts' household between 1786 and 1788, suffered

\footnotetext{
${ }^{5}$ Denis Diderot, 'Letter on the blind for the use of those who see', in Margaret Jourdain, trans. and ed., Diderot's early philosophical works (Chicago, IL, and London, 1916).

${ }^{6}$ For Stewart's connections to settler colonists and imperialists see Onni Gust, Unhomely empire: whiteness and belonging, 1760-1830 (London, 2020), ch. 2.

${ }^{7}$ Bojesen, 'Thomas Reid', p. 94; Elizabeth Montagu to James Beattie, London, 22 Mar. 1788, University of Aberdeen Archives and Special Collections, MS 30/2/566, n.p.

${ }^{8}$ Imelda Clift, The Wedgwood/Darwin dynasty (Ely, 2008), p. 13.
} 
with debilitating depression, migraines, and poor eyesight throughout his life. ${ }^{9}$ Stewart himself was overcome with grief when his son, George, died in 1809; George had suffered with ill-health for at least a year, during which Stewart's own duties and studies had been put on hold in an attempt to find a remedy. ${ }^{10}$ The same year, Stewart was visited in Edinburgh by Maria Dundas, later known for her travel writing on India and South America, which she published under her married name, Maria Graham. Her visit to Edinburgh with her father and sister was undertaken partly in order to deliver her younger brother to Braidwood's Academy for the Deaf and Dumb, an institution that Stewart himself was extremely interested in. ${ }^{11}$

The reoccurrence of discussions of disabling diseases in the letters and diaries of elites supports Turner's argument that disability was highly prevalent and visible in eighteenth-century society. ${ }^{12}$ Although eighteenth-century narratives of the experience of disability are few and far between, sources do exist that reveal first-person thinking about the position of those with bodily impairments. Mary Prince, an enslaved African woman who travelled to England in 1828, described her own physical disabilities as a result of brutal labour regimes and physical punishment, as well as the physical impairments of her fellow enslaved Africans, including 'poor Daniel' who was 'lame in the hip'. ${ }^{13}$ More commonly, it is the experiences of elites that survive in the historical record. Lady Mary Wortley Montagu's poem 'Town Ecologues: Saturday, the small-pox' draws on her own experience of smallpox to critique the commodification of beauty by illustrating the terrors of physical disfigurement for elite, white women, whose beauty was the only source of power. ${ }^{14}$ Neither did the burden of normative standards of beauty fall only on the shoulders of women. The Spectator's ridicule of the 'Ugly Club' shows how elite men, too, could be stigmatized as a result of physical difference, albeit with less socio-economic consequences than for women. William Hay, MP for Seaford, born with a spinal curvature, wrote of his own experiences of physical impairment in what has been hailed as the first 'disability' manifesto. ${ }^{15}$ Hay's Deformity: an essay is perhaps unique in its bringing together of personal experience with philosophical questioning, but it illustrates David Wright's point that the disabled became increasingly important 'test cases,

\footnotetext{
${ }^{9}$ Gordon Macintyre, Dugald Stewart: the pride and ornament of Scotland (Brighton, 2003), p. 51; Trevor H. Levere, 'Wedgwood, Thomas (1771-1805)', Oxford dictionary of national biography (Oxford, 2004; online edn, May 2008) (www.oxforddnb/view/article/28967, accessed 9 Apr. 2015).

${ }^{10}$ Dugald Stewart to William Drennan, Belfast, by Port Patrick, from Cairmur by Cowden burn, Tweedale, 20 Sept. 1808, National Library of Scotland, d.12.30, n.p.; Macintyre, Dugald Stewart, pp. 147-9.

11 Maria Graham, 'Reminiscences', in Rosemary Brunel Gotch, ed., Maria, Lady Callcott: the creator of 'Little Arthur' (London, 1937), p. 71.

12 Turner, Disability in eighteenth-century England.

${ }^{13}$ Mary Prince, The history of Mary Prince, a West Indian slave, related by herself (London, 1831). See also Stefanie Kennedy, "Let them be young and stoutly set in limbs": race, labor and disability in the British Atlantic world', Social Identities, 21 (2014), pp. 41-2, 48.

${ }^{14}$ Nussbaum, The limits of the human, p. 119.

${ }^{15}$ Deutsch and Nussbaum, 'Introduction', in 'Defects', pp. 2-3.
} 
as quasi-experimental subjects of a more generalized Enlightenment project'. ${ }^{16}$ As Wright points out, the focus of philosophical questioning was often on people, and particularly children born with sight, hearing, and speech impairments. It was in this context of pervasive impairment and philosophical discussion over the relationship between the senses and the mind that Dugald Stewart presented his thoughts on James Mitchell, a young man living in Nairnshire, in the Highlands of Scotland, who was born deafblind and was consequently also unable to communicate orally, upon which this article will now focus.

\section{III}

Although not the most original thinker, or the most prolific writer, of the Scottish Enlightenment, Stewart was very much a part of that social and intellectual world. ${ }^{17}$ He was well acquainted with the words, and the worlds, of Adam Smith and William Robertson, whose works he collected for publication after their deaths and whose biographies he wrote. He also attended, and subsequently inherited, Adam Ferguson's lectures on Moral Philosophy, and was briefly a student of Thomas Reid at the University of Glasgow in $1771 .^{18}$ Although based at the University of Edinburgh throughout his life, Stewart had close ties with the 'Common Sense' school of philosophers in Aberdeen, as well as with thinkers in France and the German principalities, including Benjamin Constant and Madame de Staël. From the 1790s, Stewart published a number of volumes on Moral Philosophy-Outlines of Moral Philosophy (1793), and A dissertation on Moral Philosophy (1824), as well as his three-volume Elements of the philosophy of the human mind $\left(1792,1814\right.$, and 1827). ${ }^{19}$ Yet his influence as a thinker owes less to his published work, and more to his role as a teacher and mentor at the University of Edinburgh for forty years. Stewart taught Moral Philosophy, and later Political Economy, to three generations of young men, many of whom would go on to become writers, politicians, and imperial administrators. Although his classrooms were closed to women, he was closely acquainted with a number of prolific female writers, including Maria Edgeworth, Elizabeth Hamilton, and Maria Graham; his second wife, Helen D'Arcy was a well-known poet. ${ }^{20}$

\footnotetext{
${ }^{16}$ David Wright, Downs: the history of a disability (New York, NY, 2010), p. 33.

${ }^{17}$ See Knud Haakonssen and Paul Wood, 'Introduction', History of European Ideas, 38 (2012), pp. 1-4; and Donald Winch, 'The system of the north: Dugald Stewart and his pupils', in Stefan Collini, Donald Wince, and John Burrow, eds., That noble science of politics: a study in nineteenthcentury intellectual history (Cambridge, 1983), pp. 23-61; Paul Wood, 'Dugald Stewart and the invention of the Scottish Enlightenment', in Paul Wood, ed., The Scottish Enlightenment: essays in reinterpretation (Rochester, NY, 2000), pp. 1-35. See also Gordon Macintyre's biography, Dugald Stewart: the pride and ornament of Scotland (Brighton, 2003).

${ }^{18}$ Macintyre, Dugald Stewart, p. 21.

${ }^{19}$ See Michael Brown, 'Stewart, Dugald (1753-1828)', Oxford dictionary of national biography (Oxford, 2004; online edn, May 2008) (www.oxforddnb.com/view/10.1093/ref:odnb/ 9780198614128.001.0001/odnb-9780198614128-e-26471, accessed 15 Mar. 2021).

${ }^{20}$ Jane Rendall, "Elementary principles of education": Elizabeth Hamilton, Maria Edgeworth and the uses of common sense philosophy', History of European Ideas, 39 (2013), pp. 613-30.
} 
Stewart's 'Some account of a boy born blind and deaf was published in Transactions of the Royal Society of Edinburgh in 1815 and then republished in the third volume of Elements of the philosophy of the human mind (1827). ${ }^{21}$ Although it was his first, and only, publication dedicated to discussing questions of disability, it is clear that his interest in physical impairment went back at least twenty years prior to the publication of the 'Account'. Students' notes from his lectures on Moral Philosophy, dating back to 1793, record references of blindness, deafness, and physical differences as part of his discussion of human capacities. ${ }^{22}$ It is also clear from these notes that Stewart's understanding and perception of physical impairment, particularly deafness, changed over the course of his lifetime. Whereas his earlier lectures are relatively dismissive of the capacities of people born deaf, referring to them as 'in a state of mental debility approaching to the condition of idiots', his later lectures focus more on the progress made in educating the deaf. Citing the work of famous educators of the deaf, Thomas Braidwood and the Abbé de l'Épée, as well as essays from the Transactions of the Royal Society, Stewart's later lectures employ a more sympathetic and respectful tone, as well as illustrating a greater depth of understanding about physical impairment in general, and deafness in particular. (It is strange that although Stewart engaged extensively with his friend and fellow Scottish philosopher, Lord Monboddo, on language, he did not make any reference to Monboddo's discussion of deafness in of the origin and progress of language. ${ }^{23}$ ) By the time Stewart gave his paper on Mitchell at the Royal Society, his philosophical interest in impairment as part of the study of the human mind was clearly well known amongst a wide network of scholars, amongst whom he was represented as an authority. In their review of Stewart's paper, for example, The Edinburgh Review stated its confidence in Stewart, stating that Mitchell's 'case' had 'fortunately fallen into the hands of one of the greatest master of the philosophy of the human mind'. ${ }^{24}$

\footnotetext{
${ }^{21}$ Dugald Stewart, 'Some account of a boy born blind and deaf, collected from authentic sources of information; with a few remarks and comments', Transactions of the Royal Society of Edinburgh, 7 (Edinburgh and London, 1815), pp. 5-78; Dugald Stewart, Elements of the philosophy of the human mind, III (London, 1827), reprinted in Sir William Hamilton, ed., The collected works of Dugald Stewart, IV (Edinburgh, 1854), pp. 300-72. Our references refer to this latter version.

${ }^{22}$ See Sofias Walker, 'Abbreviations from Lectures on Moral Philosophy, 1778-9', Edinburgh University Archives (EAU), Gen 2023, vol. 2; Anon., 'Lectures on Moral Philosophy delivered by Prof Dugald Stewart, 1789 and 1790', EUA, Gen 1987-9; Archibald Bell, 'Lectures on Moral Philosophy by Dugald Stewart, delivered at the University of Edinburgh, 1793-4', EUA, Dc4.97; J. Lee Eden, 'Attendance at class, 1796, -7, -8, -9', EUA, Dc8.143; James Bridges, 'Lectures on Moral Philosophy, 1801-2', EUA, Dc5.88; John Dow, 'Lectures on Political Economy by Dugald Stewart, 1808-9', EUA, Dc.3105, vol. 1; Archibald Alison, 'Lectures on Moral Philosophy, 1808', EUA, Gen. 1382-5, vols. 1-4.

${ }^{23}$ See Jules Paul Siegel, 'The Enlightenment and the evolution of a language of signs in France and England', Journal of the History of Ideas, 30 (1969), n. 39, p. 113.

${ }^{24}$ Art XII. Some account of a boy born blind and deaf. By Dugald Stewart, Esq. F.R.S. Edinburgh, \&c. (Read before the Royal Society of Edinburgh.) 4to. pp. 70 in The Edinburgh Review, or Critical Journal for July 1812 to Nov. 1812, v.20 (Edinburgh, 1812), p. 468.
} 
Mitchell's case clearly interested a wide range of philosophers, many of them members of the Royal Society. Stewart included their correspondence about the boy's situation as part of his 'Account', so that the essay itself becomes less an individually authored piece and more a pastiche of observations and interjections. Stewart had first been alerted to Mitchell's situation by James Wardrop (1782-1869), an opthalmic surgeon, who had studied Moral Philosophy under Stewart during his period as a student at Edinburgh University. ${ }^{25}$ Wardrop dedicated his own account of Mitchell's impairments and the operation he performed in an attempt to remove his cataracts, published in 1813, to Stewart. He concluded his account by acknowledging Stewart's 'lively interest' in the case and his hope that 'everything will be done which can promote the happiness of this interesting youth, whilst science will reap the benefit of the observations of one of the most ingenious and most profound philosophers of the present day'. ${ }^{26}$ George Glennie, Professor of Moral Philosophy at Marischal College, Aberdeen, had gained an account of Mitchell's situation through the auspices of a local clergyman to whom he posed a number of questions. The answers to his 'Queries' are included in Stewart's 'Account', as are the supplementary observations and correspondence between John Gordon, a doctor and member of the Royal Society, and Stewart. The well-known philosopher, historian, and member of parliament for Nairnshire, Sir James Mackintosh, also visited the Mitchell family in 1812 and reported his observations to Stewart. This philosophical interest in James Mitchell was sustained throughout Stewart's lifetime, and beyond; in the version published in Collected works, a note added by the editor, Sir William Hamilton, brings James Mitchell's history up to 1854, whilst the last account addressed to Stewart is dated 1826, two years before his own death and fourteen years after his initial encounter with Mitchell, thus revealing a sustained interested in Mitchell's case. These essays, reports, and letters between scholars and friends illustrate the way that philosophical debate and knowledge formation was consolidated through formal and informal networks.

'Some account of a boy born blind and deaf' introduces the reader to the fourteen-year-old James Mitchell, a clergyman's son, who lived with his parents and five siblings in Ardclach in Nairnshire in the Scottish Highlands. The details of Mitchell's situation and habits were represented by his older sister, Jane Mitchell, who appears to have acted as a gateway to the world for Mitchell, and as an interpreter of his world to the various people who were interested in him. In a letter to Stewart, Glennie wrote that Jane 'seems to have a greater ascendancy over him, and more power of managing him than any other person'. ${ }^{27}$ She was able to communicate to James using basic signs addressed to his sense of touch (such as patting him on the

\footnotetext{
25 'James Wardrop', in The Royal College of Surgeons of Edinburgh, https://archiveandlibrary. rcsed.ac.uk/surgeon/3771486-james-wardrop, accessed 15 Mar. 2921.

${ }^{26}$ James Wardrop, History of James Mitchell, a boy born blind and deaf, with an account of the operation performed for the recovery of his sight (London and Edinburgh, 1813), p. 43.

${ }^{27}$ Stewart, 'Some account', p. 316.
} 
head) and he was able to comprehend whether she approved of his behaviour or otherwise through these means. ${ }^{28}$ Stewart and his fellow scholars saw in Jane Mitchell a conduit through which to experiment with alternative modes of education in order to enable James to communicate his ideas, including teaching him the alphabet by relating words to feelings and experiences. ${ }^{29}$ Jane Mitchell was, Sir James Mackintosh wrote, a 'young woman of most pleasing appearance and manners, distinguished by a very uncommon degree of modesty, caution and precision in her accounts of him'. ${ }^{30}$ Clearly very impressed by her kindness to her brother, Mackintosh suggested that the habitual exercise of ingenious benevolence seems to me to have left its traces on her countenance, and to have bestowed on her naturally agreeable features, an expression more delightful than beauty'. ${ }^{31}$ Jane's role in supporting her brother conformed to Enlightenment ideals of women as thoughtful and benevolent carers. Yet her actions went much beyond that remit; she was instrumental in analysing and interpreting (rather than just observing) her brother's behaviour for the elite, male audience that gathered around him. The Edinburgh Review's reference to 'that manual language which was conceived by the Abbé de l'Épée and invented by Miss Mitchell' goes some way towards acknowledging the importance of both her role and contribution to knowledge formation. $^{32}$ In this respect, although barred by her gender from formal participation in scholarly discussions, Jane Mitchell's translation of her brother's actions played a fundamental role in wider discourses of the human mind, human development, and progress.

Stewart's 'Account' is an appeal to the sensibilities, as well as to the philosophical and anatomical interests, of his fellow scholarly men. He concluded by stating that in writing the report, 'I was partly influenced by the hope, that it may possibly be the means of securing a decent provision for the individual to whom it relates' as well as to his mother and sister. ${ }^{33}$ His reference to James Mitchell's case as a 'melancholy history' was presumably intended to rouse the charitable sentiments of his colleagues, for the essay itself appears anything but melancholy, offering a humanizing account of Mitchell whose character, naughtiness, and sensibility shines through into the narrative. ${ }^{34}$ The essay is replete with vivid details painting a picture of Mitchell's life in rural Scotland, from his interactions with servants, to his relationship with his parents and sister, to the mischief he dreamed up, to his love of tobacco and new clothes. In his letter to Stewart, Glennie claimed that 'notwithstanding his unfortunate defects' his countenance 'does by no means indicate fatuity', and went on to note that the 'lineaments of thought were very describable

\footnotetext{
${ }^{28}$ John Gordon, 'Supplement to the foregoing account of James Mitchell', in Stewart, 'Some account', p. 354.

${ }^{29}$ Ibid., p. 355.

${ }^{30}$ Sir James Mackintosh, 'Letter from Sir James Mackintosh to Mr Stewart, Edinburgh $5^{\text {th }}$ November 1812', in Stewart, 'Some account', p. 359.

31 Ibid., pp. 359-60.

32 Art XII. Some account, p. 470.

${ }^{33}$ Stewart, 'Some account', p. 336.

${ }^{34}$ Ibid., p. 300.
} 
on it', and that he adopted a range of appropriate expressions including looking 'composed and sedate' (at church and during family prayers), 'animated' (upon the appearance of a stranger), and 'feroci[ous]' (when offended or enraged). ${ }^{35}$ These 'countenances' certainly played an important role in endearing potential sponsors to support James Mitchell as a person, yet they were also fundamental to the philosophical impetus that underpinned James Mitchell as a case-study. Indeed, Stewart's appeal made clear how inseparable the two positions were when he stated that by providing financially for James Mitchell and his family, the Society would at least be preventing any 'regrets which might afterwards be felt, if so rare and opportunity for philosophical observation and experiment should be suffered to pass before our eyes, without any attempt being made to turn it to the advantage of science. ${ }^{36}$

Stewart and his correspondents' interest in James Mitchell's situation was due to its relevance to a philosophical discussion around the question: what impact does deafblindness have on the human mind? The Edinburgh Review claimed that Mitchell's case represented 'the most interesting anomalies in the natural history of the human species', whilst Wardrop described it as 'a most wonderful and instructive experiment instituted by Nature herself to illustrate the progress of human intellect, to mark the influence of the different organs of perception in the development of its various faculties; thereby realising what many philosophers have contemplated in imagination, but never before witnessed. ${ }^{37}$ Stewart himself understood his encounter with Mitchell as an opportunity of 'verifying or correcting' the surgeon William Cheselden's famous 1728 account of improving the vision of a boy upon which doubt had been recently cast. ${ }^{38}$ Cheselden's account had, amongst other things, sought to answer the 'Molyneux question' first posed by William Molyneux, whose wife was blind, and then taken up by John Locke, as to whether a person blind from birth or early infancy would, if suddenly to regain their sight as through surgery, be able to connect their tactile knowledge of certain objects (such as a cube and a sphere) with the newly acquired visual sight of them. In Cheselden's account, the boy who had been operated on could distinguish the objects placed before him as his bandage slipped off, providing proof of innate knowledge. Molyneux's question and the situation of the blind had far-reaching implications for philosophies of the human mind, and recurred in different guises across Enlightenment philosophy. ${ }^{39}$ That Mitchell was deaf as well as blind would, to Stewart's first thoughts on the subject, enhance the experiment further, but after consideration,

\footnotetext{
${ }^{35}$ Professor Glennie, 'Answers to some queries addressed to a clergyman in the county of Moray....with respect to James Mitchell, a lad sixteen years of age, who was born blind and deaf, in Stewart, 'Some account', p. 314.

${ }^{36}$ Stewart, 'Some account', p. 337.

${ }^{37}$ Art XII. Some account, p. 462; Wardrop, History of James Mitchell, p. 42.

${ }^{38}$ Stewart, 'Some account', p. 301.

${ }^{39}$ See Kate Tunstall, Blindness and the Enlightenment: an essay (London, 2011). Chris Mounsey's Sight correction: vision and blindness in eighteenth-century Britain (Charlottesville, VA, 2019) was published after we wrote the main body of this article, but it provides an important addition to the research on blindness, as well as philosophical debates on blindness.
} 
Stewart concluded that due to the considerable communications they had with Mitchell, and due to the fact that pre-surgery Mitchell already seemed responsive to light and colour, he was not a suitable candidate for furthering Cheselden's work. ${ }^{40}$ Nonetheless, James Mitchell continued to prove of great interest to Stewart and his friends who were familiar with the contemporaneous developments in France where Abbé de l'Épée and Abbé Sicard were revolutionizing deaf education. In particular, the celebrated pupil Jean Massieu, a former student and prodigy of Sicard who had been widely used to demonstrate the successes and potential of deaf education and had gone on himself to be a significant educator of deaf children, appears as a comparator in their writing. Whilst, unlike Mitchell, Massieu did not have a visual impairment, the fact that he had started his education when only two years younger than Mitchell was held as somewhat encouraging, though elsewhere the differences between the two young men were emphasized. ${ }^{41}$

The prospect of Mitchell's education was not so much considered in terms of a humanitarian or benevolent intervention but in terms of a scientific experiment in the ability of deafblind people, in general, to be educated. Such an experiment had also motivated the French deaf educationalists. As Stewart translates the preface to one of Sicard's writings on the subject, we see 'what an immense distance from other men, would a being so cruelly degraded be placed; and how difficult to transport him across that gulf by which he is separated from the rest of his species'. ${ }^{42}$ Such gulfs haunted the minds of Enlightenment thinkers; disabled people posed powerful challenges to the criteria upon which their ideas about universal manhood were based. Stewart understood Sicard's aim to be of a different and of a higher nature than simply teaching the deaf to speak. It was not, Stewart wrote, 'to astonish the vulgar by the sudden conversion of a dumb child into a speaking automaton, but, by affording scope to those means by which Nature herself has provided for the gradual evolution of our intellectual powers, to convert his pupil into a rational and moral being. ${ }^{43}$ Stewart was familiar with the French educationalists, as well as with a range of rather more obscure British educators of the deaf including the Scottish teacher and linguist George Dalgarno, demonstrating an interest in deaf education beyond what could have been gleaned from a passing interest. Indeed, in addition to their hopes of correcting Mitchell's vision and hearing through surgery, one of the intentions of Stewart's account was to devise a plan of education that would enable him to communicate with society beyond simple gesture. In a letter to Stewart published as part of the 'Account', Dr Gordon suggested using a raised surface to teach Mitchell the alphabet and eventually to read and write through touch. ${ }^{44}$ For philosophical rather than humanitarian reasons, Stewart

\footnotetext{
${ }^{40}$ Stewart, 'Some account', p. 306.

${ }^{41}$ Ibid., p. 333. For more on Massieu, see Harlan Lane, When the mind hears: a history of the deaf (London, 1984), pp. 17-24.

${ }^{42}$ Sicard quoted in Stewart, 'Some account', p. 328.

${ }^{43}$ Stewart, 'Some account', p. 332.

${ }^{44}$ John Gordon, 'Letter from Dr Gordon to Mr Stewart, Edinburgh, October 26, 1812', in ibid., p. 355.
} 
regretted that these plans were never put into action: "how invaluable was the opportunity which has been thus lost of adding to the Natural History of the Human Mind'. ${ }^{45}$

Stewart understood James Mitchell's 'case' to provide valuable insights into a debate over the relationship between the mind and the body, and the individual and society. From the early eighteenth century, sensory impressions took on an increasingly important role in philosophical understandings of the constitution of the human mind. As G.J. Barker-Benfield has illustrated, the discussion of 'sensibility' derived from Isaac Newton's work into sight and optics, in which he had posited visual perception as the grounds upon which truth was established. Newton's theory was developed and taken in a different direction by John Locke, who argued that the mind gained understanding through the impressions that were made upon it by perceptions, and that it was these impressions that formed the foundation of knowledge and identity. The argument became the basis upon which scholars, including Descartes, Hartley, and Helvetius, developed arguments for the co-relationship between physical sensibility and the workings of the human mind. ${ }^{46}$ At the centre of this dispute were versions of the Cartesian question of the mind/ body duality, which scholars discussed, in part, through a consideration of the distinction between humans and animals. Were animals mere material automatons who lacked a mind (and therefore a soul) as Descartes implied? Or was there a constitutive relationship between the body and the mind that endowed animals, as well as humans, with the ability to think, as Erasmus Darwin amongst others claimed ${ }^{47}$ In the third volume of his Elements of the philosophy of the human mind, Stewart navigated these questions by arguing that although animals and humans had many faculties in common, only humans had the ability to use reason. He defined 'reason' as the 'capacity of carrying on processes of thought by the help of artificial signs and arriving at scientific conclusions' ${ }^{48}$ Stewart's use of 'artificial signs' aligned him with Thomas Reid's 'Common Sense' philosophy, which made a distinction between 'natural signs' representing universal and God-given meaning, and 'artificial language', which referred to the meaning developed by humans in society. ${ }^{49}$ For Stewart, 'man' was unique amongst sentient beings for 'his' ability to categorize meaning, communicate that meaning through language, and employ those ideas to affect future change and 'progress'.

Physical impairments provided important case-studies for this philosophical discussion about the relationship between the body and the mind, and

\footnotetext{
${ }^{45}$ Stewart, 'Some account', p. 370.

${ }^{46}$ G. J. Barker-Benfield, The culture of sensibility: sex and society in eighteenth-century Britain (Chicago, IL, 1996), ch. 1; Sarah Knott, Sensibility and the American Revolution (Chapel Hill, NC, 2009), pp. 9-11.

${ }^{47}$ See Stewart, 'Faculties of man and brutes compared', in Elements, III, pp. 250-99.

${ }^{48}$ Stewart, Elements, III, p. 295.

${ }^{49}$ Stewart defines the difference between 'natural' and 'artificial' signs, as well as his debt to Reid, clear in his lectures on Moral Philosophy. See, for example, Archibald Alison, 'Lectures', EUA, Gen 1382-3, 1808-9, pp. 77 and 2. For the wider context, see Knud Haakonsen, Natural law and Moral Philosophy: from Grotius to the Scottish Enlightenment (Cambridge, 1996), ch. 7.
} 
ultimately what constituted the human. In Elements, as in his earlier lectures on Moral Philosophy, Stewart cited debates dating back to Aristotle and Galen over the necessity of touch, and thereby of hands, to the human imagination. He dismissed the idea that hands were fundamental to the development of human ingenuity by citing an example of a woman named Biffin from Somersetshire who had no hands and so used her mouth and tongue to do embroidery, and could write by holding a pen between her cheek and shoulder. Stewart had met this woman in Edinburgh and concluded that 'her intellectual powers seem to me far above the ordinary level, and the expression of her countenance (in particular of her eye) was good-humoured and cheerful, yet thoughtful and interesting, ${ }^{50}$ This evidence, as well as the example of a German man called Buckinger who had been exhibited in Edinburgh earlier in the eighteenth century for his ability to play musical instruments, write, and draw despite not having arms or legs, proved that it was the human mind that was fundamentally different from that of animals. ${ }^{51}$ James Mitchell's case, however, proved an additional challenge, because his lack of ability to communicate rational ideas either through written or oral communication raised the question of whether he possessed rationality. As Stewart explained in a footnote to the introduction of his 'Account of a boy', the details of Mitchell's case 'bear on some of the most interesting questions which relate to the characteristical endowments of the human mind, ${ }^{52}$ Key questions posed to Jane Mitchell by Mr Glennie about her brother, and reported to Stewart - 'Does he discover any sense of danger?'; 'Has he knowledge of the use of things?'; 'Does he love to associate with boys, and engage in play?'; 'Does he apprehend the distinction of ranks?' - were all designed to understand the extent of his cognition, and therefore his humanity. ${ }^{53}$

Stewart and his colleagues were particularly interested in Mitchell's ability to learn from his actions, feelings, and experiences in the past, in order to anticipate the future. Stewart relates numerous instances, including being discouraged from crossing a narrow and perilous bridge over some rapid water near the manse by being pushed into the river (at a safer part), ${ }^{54}$ jumping out the way of horse and carts after he had been run over by one, ${ }^{55}$ and worrying that he would lose his sister after the death of his mother, in order to confirm that Mitchell was as capable as an able-bodied person of acting rationally upon the basis of experience. ${ }^{56} \mathrm{John}$ Gordon, a doctor who also wrote to Stewart about the case, remarked that 'The train of his thoughts seem to be regulated by that of the same principles as the soundest minds. His actions neither indicate incoherence nor fatuity; but everything he does appears capable

\footnotetext{
${ }^{50}$ Stewart, Elements, III, pp. 285-6.

${ }^{51}$ Ibid., p. 285.

52 Stewart, 'Some account', p. 300.

${ }^{53}$ Glennie and Miss Jane Mitchell, 'A series of questions respecting James Mitchell', in Stewart, 'Some account', pp. 346-8.

${ }^{54}$ Gordon, 'Supplement', p. 322.

${ }^{55}$ Jane Mitchell, 'Letter from Jane Mitchell to Sir T. Dick Lauder', in Stewart, 'Some account', p. 363.

${ }^{56}$ Ibid., p. 362.
} 
of being easily traced to rational motives. ${ }^{57}$ Those writing of Mitchell were also at great pains to stress that he experienced a range of emotions from grief, on the death of his father, to curiosity - his predominant feeling when a stranger entered the manse, to joy and mirth. The grief James Mitchell felt upon his father Mr Mitchell's death is returned to several times, by the different contributors to the series of letters of which the essay is largely composed and is highly significant. Although the exact manner in which James Mitchell conducted himself was somewhat disputed, all agreed that he experienced sorrow, grief, and a realization of the loss he had sustained. The later death of his mother, and suspected fears that he might one day lose his sister, is also discussed in this regard. Mitchell's expression of emotion, albeit through non-linguistic means, provided proof not only of his inherent humanness, but also of his relative refinement despite his lack of formal education and his apparent solitude and isolation in 'the midst of society'. ${ }^{58}$ Despite his differences from early eighteenth-century philosophers of moral sentiment, Stewart generally agreed that great susceptibility to both physical and emotional pain was indicative of a higher level of sensibility, refinement, and civilization. According to this paradigm, the capacity to feel was a signifier of difference, demarcating the boundary between 'civilized' and 'savage', and intersecting with this binary, between the human and the animal.

That James Mitchell was clearly susceptible to 'benevolent feelings' provided proof that disabled people, despite, in some cases, their limited ability to interact with society using language, were capable of a complex range of emotions. This was important because it suggested that disabled people, and those with sensory impairments in particular, were able to affectively relate to, and identify with, another person's experience - an ability that Smith referred to as 'sympathy'. 'Sympathy', Smith had argued in Theory of moral sentiments (1759), was what enabled humans to form connections to each other as part of society, and motivated them towards acts of virtue..$^{59}$ If people with disabilities, and particularly sensory impairments, were able to feel sympathy then they would necessarily be capable of virtue, too. In his essay 'Of deformity' (1612), Francis Bacon had argued that that deformity, whilst not a sign of innate sin, would necessarily impair the development of a virtuous character because of the disadvantages that the 'deformed' face in society. Apparently being 'void of natural affection', Bacon argued that 'deformed persons' are 'extreme bold', habituated to exposure to 'scorn' and 'stirrith' in 'industry' they 'watch and observe the weakness of others, that they may have somewhat to repay'. ${ }^{60}$ William Hay's response, in his Deformity: an essay (1754), argued that because the disabled did not automatically gain society's approbation, and had

${ }^{57}$ Gordon, 'Supplement', p. 322.

${ }^{58}$ Stewart, 'Some account', p. 300.

${ }^{59}$ Adam Smith, The theory of moral sentiments. Or, an essay towards an analysis of the principles by which men naturally judge concerning the conduct and character, first of their neighbours, and afterwards of themselves. To which is added, A dissertation on the origins of language (4th edn, Edinburgh and London, 1774; first published 1759).

${ }^{60}$ Francis Bacon, 'Of deformity' (1625), in The essays, or councils, civil and moral of Sir Francis Bacon (London, 1696), p. 117. 
to work harder to show their virtues in order to counter prejudice, they ultimately achieved more goodwill from able-bodied members of society than those whose exterior beauty raised expectations of inner virtue. ${ }^{61}$ In effect, Hay argued that the disabled, or at least elite men with disabilities, were likely to be more virtuous than their able-bodied contemporaries. Although Stewart did not reference either essay, his narrative of James Mitchell provided evidence of the ability of people with sensory impairments to interact meaningfully and benevolently with the rest of the world, as well as to earn a degree of affection from society at large.

\section{IV}

Stewart published the 'Account of James Mitchell' in Transactions of the Royal Society of Edinburgh, the vehicle of the Royal Society, which was established in 1665 in order to gather and support scientific knowledge. The Society primarily comprised men of high social status, with some from the middling orders, who were actively engaged with a wide range of natural philosophy. ${ }^{62}$ As post-colonial and feminist scholars have long argued, the ideas of this group played a constitutive role in consolidating and naturalizing hierarchies of human difference that developed during the Enlightenment period. Classifying human bodies on the basis of phenotype, anatomy, and reproductive capacity, Enlightenment thinkers represented the white, able-bodied male as the normative standard against which all other bodies were situated and judged. ${ }^{63}$ In this final section of this article, we place Stewart's representation of Mitchell's life in the context of historiographical critiques of Enlightenment discourses of difference in general, taking an intersectional approach to situate disability alongside other constructs of difference in Stewart's writing, principally race. We ask to what extent Mitchell was defined through the same discourses of difference that dehumanized non-white Others. What are the limits and possibilities of adding 'disability' to the ideology of white, male supremacy that haunts modern Europe, as well as its former and contemporary colonies? And what does exploring disability alongside race do to expose the limits of 'universal' theories of human nature in the Enlightenment 'science of man'?

Work on the history of disability has emphasized the presence of discourses of dehumanization and freakery in the construction of what it meant to be disabled ${ }^{64}$ Under the guise of 'scientific curiosity' and the development of 'natural history', the Royal Society, like many male-only Enlightenment

\footnotetext{
${ }^{61}$ William Hay, Deformity: an essay (London, 1754), pp. 18-19.

${ }^{62}$ Richard Sorrenson, 'Towards a history of the Royal Society in the eighteenth century', Notes and Records of the Royal Society of London, 50 (1996), pp. 29-46.

${ }^{63}$ Ann Stoler, 'Reason aside: reflections on Enlightenment and Empire', in Graham Huggan, ed., The Oxford handbook of post-colonial studies (Oxford, 2013), pp. 39-66; Felicity Nussbaum, Torrid zones (Baltimore, MD, and London, 1995), epilogue; Mary Louise Pratt, Imperial eyes: travel writing and transculturation (London and New York, NY, 1992), ch. 1.

${ }^{64}$ See, for example, Rosemarie Garland Thomson, Extraordinary bodies: figuring physical disability in American culture and literature (New York, NY, 1997).
} 
institutions, configured certain bodies as objects, rather than as agents. In some respects, Stewart's representation of James Mitchell as a 'rare' example of a case-study that provided 'data for some important conclusions concerning the capacities of the Human Mind, considered in contrast with the instincts of Brutes', supports this critique. ${ }^{65}$ As the letters between scholarly gentlemen suggest, Mitchell also appears to have become something of a landmark curiosity in the Highlands of Scotland, a region that was itself the focus of the elite touristic gaze during this period. At the same time, however, the 'Account' lacks the kind of affective de-humanization that would seem to accompany the emergence of what Rosemarie Garland Thomson refers to as a modern 'freak discourse'. Thomson argues that the Enlightenment period saw the transformation of aberrant bodies from 'prodigious monsters' to 'the abnormal, the intolerable'. Displayed as objects in museums and exhibitions, or institutionalized in hospitals for medical observation, 'freaks' were denied agency and humanity. ${ }^{66}$ This is in stark contrast to representations of James Mitchell's life. Living in his family home, it is clear from the accounts provided that James Mitchell was able to exert a considerable amount of agency over his servants, family, and friends - whatever his speech and language difficulties, he was not an isolated individual or one confined within an institutional setting, nor, in the neighbourhoods where he was well known, was he treated as a 'freak'. The ability of Mitchell to communicate with his social network and they with him, albeit to a limited degree, suggests a tacit acceptance of disability as a fact of life that did little to diminish from a sense of belonging to the family, the community, or class hierarchy.

But this did not mean that Mitchell's condition was unconditionally accepted. Another trope in the way in which disability starts to be seen in the modern period is thinking about disability not simply as a God-given way of being, but as a 'problem' that needed treatment and, increasingly, medical intervention. Stewart and his friends understood Mitchell as a body that needed fixing, despite the fact that there were no obvious signs that he was unhappy as a result of his impairments, and that he was clearly distressed by the attempts to operate on his eyes. ${ }^{67}$ Nonetheless, Stewart hoped that Mitchell would regain more sight through surgical interventions, and also believed that education would also improve his situation. This ambition ties in with ideas of the 'perfectability' of human nature and human societies, which was a key component of Thomas Reid's 'Common Sense' philosophy. In his Inquiry into the human mind on the principles of common sense (1764), Reid had argued that

savage hath within him the seeds of the logician, the man of taste and breeding, the orator, the statesman, the man of virtue, and the saint; which seeds, though planted in his mind by nature, yet through want

\footnotetext{
${ }^{65}$ Stewart, 'Some account', p. 335.

${ }^{66}$ Rosemarie Garland Thomson, 'Introduction', in Thomson, ed., Freakery: cultural spectacles of the extraordinary body (New York, NY, 1996), pp. 4-5. See also Sadiah Qureshi, 'Displaying Sara Baartman, the "Hottentot Venus", History of Science, 42 (2004), pp. 233-57.

${ }^{67}$ Gordon, 'Supplement', p. 320.
} 
of culture and exercise, must lie for ever buried, and be hardly perceivable by himself or by others. ${ }^{68}$

Stewart developed his mentor's position, but placed more emphasis on the role of education in perfecting and civilizing humankind. Education, he argued in the first volume of Elements of the philosophy of the human mind, was key to 'guiding the intellectual and moral powers' in order to 'cultivate although the various principles of our nature, both speculative and active, in such a manner as to bring them to the greatest perfection of which they are susceptible ${ }^{69}{ }^{69}$ By attempting to develop a system through which to educate James Mitchell, Stewart and his contemporaries were endeavouring to prove that the human mind was capable of 'perfectibility' even where the body was not itself 'perfectly' formed.

Both Reid's and Stewart's notions of 'perfectibility' intersected with ideas of racial superiority. Unlike their colleagues, including Lord Monboddo, neither Reid nor Stewart were explicitly engaged in emergent race science, with its focus on explaining Africans' darker skin tone in an attempt to resolve questions about the origins of humankind. ${ }^{70}$ Stewart was explicitly critical of the slave trade and slavery in the Americas, stating that it is a reproach to those enlightened times that after slavery has been banished from Europe, it should be again revived in the European colonies'. ${ }^{71}$ Yet neither did Stewart or Reid ever question the superiority of white, European "civilization', and whether they intended it or not, the philosophical arguments about perfectibility enabled a discourse of white supremacy. Reid may have understood every human to have the potential for 'civilization', but that did not mean that every society would necessarily 'thrive and grow up to great perfection'. Some societies, he argued, would take a 'perverted' course, others would stall on the route to perfection, and still others would die out completely. ${ }^{72}$ The extermination of certain 'races', understood as part of a Divine Plan, provided 'enlightened' imperialists with a way of denying any responsibility for the annihilation of Native Americans and, later Aboriginal Australians, as a result of settler colonialism. It would take until mid-nineteenth-century eugenics, however, for the same logic to be explicitly applied to disabled people.

\footnotetext{
${ }^{68}$ Thomas Reid, An inquiry into the human mind on the principles of common sense (London, 1823), p. 4.

${ }^{69}$ Dugald Stewart, Elements of the philosophy of the human mind, I (London, 1792), p. 11.

${ }^{70}$ Silvia Sebastiani, 'Challenging boundaries: apes and savages in Enlightenment', in Silvia Sebastiani, Wulf Hund, and Charles Mills, eds., Simianization: apes, gender, class and race (Zurich, 2015), pp. 105-38; Silvia Sebastiani, The Scottish Enlightenment: race, gender, and the limits of progess (Basingstoke, 2013), ch. 3; Colin Kidd, The forging of races: race and scripture in the Protestant Atlantic world (Cambridge, 2006); Andrew Curran, The anatomy of blackness: science and slavery in an age of Enlightenment (Baltimore, MD, 2011); Roxann Wheeler, The complexion of race: categories of difference in eighteenth-century British culture (Philadelphia, PA, 2000).

${ }^{71}$ Walker, 'Abbreviations', p. 365.

${ }^{72}$ Reid, An inquiry, p. 4. For a discussion of Stewart's relationship to Reid and 'Common Sense' philosophy, see C. B. Bow, Common sense in the Scottish Enlightenment (Oxford, 2018), ch. 9.
} 
When positioning disability intersectionally, in regards to the Scottish Enlightenment, it is possible to see that many of the same tropes appear when attempting to assess the 'humanity' of those considered Other. In particular, language, an ability to learn from experience, and the experience of pain return as particularly dense markers of a person's rationality and subjectivity. Stewart believed that language itself was not necessarily indicative of humanity, and critiqued the conflation between 'the gift of Speech' and 'the gift of Reason' in his colleagues' attempts to educate people who could not communicate orally. Speech, he argued, could be taught to parrots and starlings; what was far more important was to "unfold silently the latent capacities of the understanding. ${ }^{73}$ It was this capacity for understanding that Stewart was keen to perceive in James Mitchell, partly as a way of proving a universal argument about human capacities. Although he did not offer any explicit conclusions regarding Mitchell's case, Stewart suggested that his evident ability to learn from experience, despite his inability to communicate using spoken or written language, proved that this capacity was innate to humans. That Mitchell's physical impairments did not prevent him from using reason or imagination supported Stewart's argument that it was the human mind, rather than any specific physical attribute, that rendered humans superior to animals.

Yet if we turn from Stewart's account of Mitchell to his discussion of racial difference, and particularly the nature and character of enslaved Africans, an ambivalence sets in about the idea that all human beings had the capacity for reason and imagination. Although Stewart believed that Africans shared the same origins as white Europeans, he repeatedly emphasized Africans' supposed intellectual inferiority, stating in his lectures that 'the intellectual powers [of Black people] are commonly supposed to be greatly inferior to many of the whites. ${ }^{74}$ In contrast to Stewart's examples of disabled Europeans, whose ingenuity in overcoming the obstacles presented by physical impairment enabled them to contribute to literature and art, Stewart saw no such potential in Africans. Citing Thomas Jefferson's Notes from Virginia, Stewart stated that 'Mr Jefferson rates their intellectual faculties very low...He doubts much if any of them could be made to understand a proposition of Euclid. No composition on any subject, whether in verse or prose, has been made by them. ${ }^{75}$ Furthermore, Stewart argued that Africans, like all 'savages', acted only in response to their present circumstances, and were incapable of anticipating the future consequences of their actions: 'it seems pretty evident that their minds are totally occupied by their present sensations. ${ }^{76}$ This statement placed Africans in much closer proximity to 'brutes', who Stewart stated in Outlines of Moral Philosophy 'are incapable of looking forward to consequences or of composing together the different gratifications of which they are susceptible and accordingly, as far as we are able to perceive, they yield to every

\footnotetext{
${ }^{73}$ Stewart, Elements, III, pp. 337-8.

${ }^{74}$ Bridges, 'Lectures', pp. 355-6.

75 Bell, 'Lectures', p. 136.

${ }^{76}$ Ibid., p. 31.
} 
present impulse. ${ }^{77}$ In contrast, Stewart stated that James Mitchell possessed a 'prudential sagacity' despite his hearing, sight, and speech impairments. Fundamental to this was Mitchell's ability to anticipate the future based on his experience of the past. In their final assessment of Mitchell, both Gordon and Stewart asserted that he possessed a good memory and 'a foresight which enables him to look forward with dread to the possibility of future contingencies' ${ }^{78}$

The radical differences between Stewart's general assessment of the abilities of Africans as a 'race' and his sympathetic assessment of the abilities and potential of James Mitchell complicates attempts to read racism and ableism as part of the same analytical framework. Whereas Stewart represented Africans as a homogeneous and animalistic mass, the detailed analysis of James Mitchell gave him humanity and individuality. This cannot simply be attributed to a lack of knowledge of any individual of African descent. Although Stewart had never visited any part of Africa, North America, or the Caribbean, he would have been familiar with Monboddo's Black servant, Joseph, and probably also the writing of Ouladah Equiano. ${ }^{79}$ Rather, Stewart's nuanced and humanizing investigation of Mitchell's situation, and his homogenization of Africans as 'savages', represent two extremes of Enlightenment analytical modes. The combination of Mitchell's whiteness and his socio-economic status informed the way that Stewart and his Scottish Enlightenment colleagues represented his situation and potential. As a member of an educated and 'respectable' Scottish family, Stewart viewed Mitchell as an equal, whose impairments elicited his sympathy. Commentators described his mother as an 'intelligent and sensible lady' and heaped praise upon his sister Jane's commitment to his welfare. Mitchell's father was well respected enough to merit a call for subscriptions towards the publication of his sermons and an autobiography, written by Reverend Simon Fraser, upon his death in 1812 (the book appears never to have gone to print). ${ }^{80}$ The Mitchell family's socio-economic status thus translated into a cultural capital that invested Stewart and Gordon with greater hope about the potential to "cultivate the intellectual and moral faculties of a human being, destitute of the two senses which are the ordinary vehicles of all our acquired knowledge', and informed their interpretation of Mitchell's disability. ${ }^{81}$

Yet if we move beyond the singular and individualized case of James Mitchell, to situate the 'Account' in relationship to Stewart's wider discussion of disability in his lectures in Moral Philosophy, it is clear that his

\footnotetext{
${ }^{77}$ Dugald Stewart, Outlines of Moral Philosophy. For the use of students in the University of Edinburgh (Edinburgh, 1793), p. 103.

${ }^{78}$ Stewart, 'Some account', p. 370.

${ }^{79}$ James Boswell, The journal of a tour to the Hebrides with Samuel Johnson (London, 1785), ed. Peter Levi (London, 1984), p. 201. For the Black presence in Britain, see David Olusoga, Black and British: a forgotten history (London, 2016); Peter Fryer, Staying power: the history of Black people in Britain (London, 1984).

${ }^{80}$ Advert for 'Sermons by the Late Reverend Donald Mitchell', in Quarterly Review (Oct. 1813), p. 300.

${ }^{81}$ Stewart, 'Some account', p. 333.
} 
understanding of physical impairment does share some similarities with that of racial difference. Stewart's overall argument in Elements was that the capacity to reason, to imagine, and to make generalizations were God-given, innate, and unique to humans. Yet despite the fact that Stewart understood every human being, supposedly regardless of embodiment, to have the capacity for reason, the body itself played a fundamental role in his understanding of the realization of that capacity. What Stewart and other philosophers called 'countenance', which was expressed particularly through the muscles of the face, played an important role in revealing the inner workings of the mind. It was for this reason that Stewart and his correspondents paid particular attention to James Mitchell's 'countenance', from which, 'notwithstanding his unfortunate defects', they claimed to observe 'the lineaments of thought'. Unlike the majority of deaf people in Europe, whose countenances, Stewart claimed, were 'generally heavy and disagreeable' unless they were 'instructed to read and speak', Mitchell appeared to have gained from his society regardless of the fact that he had no 'artificial language. ${ }^{83}$

Stewart also applied this interpretation of physicality to racial and stadial difference. The 'savage', Stewart argued, spent most of his time 'in a state of stupid and thoughtless inactivity', and so his features lacked the 'sprightliness and mobility which with us indicate a quick mind' and possessed a 'sleepy, languid, and dull appearance. ${ }^{84}$ As society or an individual made progress, however, their physical countenance itself changed. ${ }^{85}$ To support his argument, Stewart cited an observation made by Samuel Stanhope Smith's An essay on the causes of the variety of complexion and figure in the human species (1787), which claimed that Africans' hair, nose, and lip shape changed when they were exposed to the more 'civilized' space of the enslavers' household ${ }^{86}$ (He ignored the well-known fact that European slave-owners routinely raped and brutalized their house slaves. ${ }^{87}$ ) 'The bodily constitution of a savage hinders him from refined speculation', Stewart concluded, 'but in time the Negroes maybe as refined as we are. ${ }^{88}$ Civilization, for disabled others and for Africans, was to be a work in progress.

Stewart's fundamental belief in the capacity of all humans to use reason formed the basis of his philosophical arguments. Yet, at the same time, he imagined the intellect necessary for 'progress' to be the particular attribute of able-bodied, elite white men. It was only through interaction with, and instruction by, these men that other people, including disabled and Black people, would be able to make progress: 'The almost idiotic or situation of person is

\footnotetext{
${ }^{82}$ Thomas Macfarlane, 'Answers addressed to a clergyman in the county of Moray by $\mathrm{Mr}$ Professor Glennie', in Stewart, 'Some account', p. 314.

${ }^{83}$ Bell, 'Lectures', p. 141.

84 Ibid.

${ }^{85}$ Walker, ‘Abbreviations', p. 364.

${ }^{86}$ Bell, 'Lectures', p. 141.

${ }^{87}$ See Diana Paton, 'Punishment, crime and the bodies of slaves in eighteenth-century Jamaica', Journal of Social History, 34 (2001), pp. 923-54; Saidiya Hartman, Scenes of subjection: terror, slavery, and self-making in nineteenth-century America (New York, NY, and Oxford, 1997).

${ }^{88}$ Walker, 'Abbreviations', p. 364.
} 
born deaf (if pains have not been taken in removing, in some degree, this defect, by education) further shows in what a low state the human intellect would remain, without material interchange of sentiments. ${ }^{89}$ Disabled people required white, able-bodied men, to lead them down the path of progress. A similar rationale - that Black people needed guiding towards 'civilization' underpinned the argument for the gradual amelioration, rather than outright abolition, of slavery. ${ }^{90}$ It was necessary to consider, Stewart stated, the effect that 'sudden emancipation would have upon the unfortunate men themselves from not being accustomed to the situation - they would be ignorant of how to conduct themselves. ${ }^{91}$ This idea that disabled and enslaved people would never achieve any form of 'civilization' and 'progress' without guidance from able-bodied white men naturalized dominance, and demanded that those in subordinate positions be grateful for the instruction that they received. ${ }^{92}$ Undoubtedly, there are many ambivalences in Stewart's writing about both race and disability and the relationship between the two is complex. Both disability and race could signify an imperative for 'correction' or 'civilization' and both subverted the norms of white, Christian, able-bodied society. To say that they were the same would be to misrepresent the specificities of each discourse both in Stewart's work and in wider Enlightenment thought, but there is certainly some reason to suggest that looking at the two in relationship with each other is a useful exercise.

\section{V}

In focusing on the 'Account' of James Mitchell, this article has explored and situated a text which, although little discussed in its own right, sheds a great deal of light on Scottish Enlightenment ideas of disability. We have argued that disability is not just a marginal curiosity in Enlightenment thought, but that for philosophers such as Stewart, it provided an important theoretical, philosophical, and humanitarian conundrum - a test case through which to provide material to questions as diverse as: what is the capacity of humanity for civilization and improvement? What role does language play in defining the limits of humanity? And to what extent did disability disrupt classed, raced, and gendered assumptions?

One of the implications of exploring these questions is that it challenges the sense in which all histories of the Enlightenment can be written without consideration of disability, or the marginalization of disability as an insignificant side-issue. Recent work has demonstrated the important ways in which the Scottish Enlightenment must be understood as a raced and gendered movement, in which bodily difference not only manifested itself in the lived

\footnotetext{
${ }^{89}$ Bell, 'Lectures', p. 66.

${ }^{90}$ Catherine Hall, Civilizing subjects: metropole and colony in the English imagination, 1830-1867 (Cambridge, 2002), p. 176; Justin Roberts, Slavery and the Enlightenment in the British Atlantic, 17501807 (New York, NY, 2013), pp. 47-56.

${ }^{91}$ Anon., 'Lectures on Moral Philosophy delivered by Professor Dugald Stewart, 1789 and 1790'.

${ }^{92}$ See George Boulukos, The grateful slave: the emergence of race in eighteenth-century British and American culture (Cambridge, 2008).
} 
experience of the (largely white and male) protagonists, but also in their thinking. Adding disability to this, and also to class as another important category, ensures that we keep in mind the extent to which issues of disability were more widely formative. ${ }^{93}$ Stewart and his friends were aware of this and of the power of disability and illness to disrupt their own lives and those of their families and friends, but they were also aware of the need to take issues of disability seriously on a philosophical level, not just to find out about the lives of disabled people, but to ask questions fundamental to their understanding of what the human body and mind was capable and to interrogate its limits. In questioning the boundaries of humanity, however, they constructed a hierarchy of embodiment, with the able-bodied, white, and elite man at the pinnacle, leading the path of 'civilization' and 'progress'. The consolidation of this paradigm during the course of the nineteenth century led to disabled people being increasingly understood as defective and aberrant, in need either of cure or assimilation to fit the norms of society, or of being eradicated entirely. Although, if read in isolation, Stewart's account of James Mitchell appears as a sympathetic and humane investigation, partly intended to help improve the life of a young man, the logic that underpinned it laid some dangerous and deeply disturbing foundations for the future.

Acknowledgements. This article is dedicated to the memory of Robert 'Bob' E. Prasch, who shared a fascination for Dugald Stewart.

Funding Statement. Esme Cleall would like to thank the Arts and Humanities Research Council (AHRC) for funding her contribution to this article through Grant AH/P003621/1 'Colonising disability: race and impairment in the British Empire'.

${ }^{93}$ Lennard Davis, Enforcing normalcy: disability, deafness and the body (London, 1995), p. 2.

Cite this article: Cleall E, Gust O (2022). Disability as a Problem of Humanity in Scottish Enlightenment Thought. The Historical Journal 65, 328-348. https://doi.org/10.1017/ S0018246X21000133 